\title{
EFFECT OF INTERNAL CAPABILITIES ON SUCCESS OF CONSTRUCTION COMPANY INNOVATION AND TECHNOLOGY TRANSFER
}

\author{
Gökhan Demirdöğen, Zeynep Işık
}

Original scientific paper Increasing competition triggered innovation and technology transfer to be the key drivers of success for companies. In this study, a construction company's success was indicated by its innovation and technology transfer performance defined with factors such as "perceived value", "project time and budget", "competitive advantage", "reputation", "productivity", "finance", "learning and development" and "customer satisfaction". Then, it was aimed to measure the effect of internal capabilities of a company such as "resources and capabilities", "project management competencies", and "strategic decisions" on success. In this context, Structural Equation Modelling method was used to analyse data collected from 52 construction companies and construct a model representing the interrelationships between the factors. According to the resulting model, it was found out that "project management competencies" have a direct relationship with "company innovation and technology transfer success" whereas, "Resources and Capabilities" and "Strategic Decisions" have both an indirect relationship with success through "project management competencies".

Keywords: construction industry; innovation; project management competencies; resources and capabilities; SEM; strategic decisions; technology transfer

\section{Učinak vlastitog potencijala na uspješnost inovacija i prijenosa tehnologije u građevinskom poduzeću}

Izvorni znanstveni članak

Povećanjem konkurencije, inovacije i prijenos tehnologije postali su ključni pokretači uspješnog poslovanja poduzeća. U ovom je radu uspjeh građevinskog poduzeća prikazan kao rezultat inovacija i prijenosa tehnologije definiranih čimbenicima poput "zapažena vrijednost", "vrijeme trajanja projekta i buđet", "konkurentna prednost", "reputacija", "proizvodnost", "financije", "učenje i razvoj", "zadovoljstvo kupca". Osim toga, cilj je bio izmjeriti učinak vlasitog potencijala poduzeća poput "resursi i potencijal", "potencijal uprave poduzeća" i "strateške odluke" na uspješnost poslovanja poduzeća. U tom smislu, metodom modeliranja konstrukcijske jednadžbe (Structural Equation Modeling) analizirani su podaci dobiveni od 52 građevinska poduzeća i napravljen je model koji predstavlja odnose između čimbenika. Prema dobivenom modelu utvrđeno je da su "potencijali uprave poduzeća" direktno povezani s "inovacijama poduzeća i uspjehom prijenosa tehnologije", a da su "resursi i potencijali" i "strateške odluke" indirektno povezane s uspjehom kroz "potencijale uprave poduzeća".

Ključne riječi: građevinska industrija; inovacije; potencijal uprave poduzeća; prijenos tehnologije; resursi i potencijal; SEM; strateške odluke

\section{Introduction}

During the last decade innovation and technology transfer strategies and activities emerged as a survival for companies to improve the consequences of economical fluctuations. Despite its conventional and stable structure, construction industry also forced to accommodate to new conditions of the business environment. The transformation began with having a knowledge based agenda and investing more on intellectual resources. Nowadays, the construction industry is basically open to innovations and technology transfer in terms of innovative material development, contracting and new construction technologies. Industrial characteristics such as collaborative structure, project-based nature, high communication requirements, site complexity, competitiveness, complex project requirements provide a tendency toward innovation and technology transfer [30]. Also construction contract constraints such as time and cost as well as the customer expectations such as quality and service foster companies for innovation. Besides, governmental regulations/standards, performance-based benchmarks, technical requirements, organizational culture and innovation strategies exert pressures on construction companies in the industry to innovate. According to [2], project-based companies exhibit differences from other companies since they produce unique and complex projects for their customers, have less hierarchy, more controlling frequency, variability against the case and condition. In construction projects, project-specific construction innovations and project management activities are generally handled together.

Contrary, in [12] the authors asserted that innovations lose their significance where project management activities dominate. The enablers surrounding construction innovations can be summarized as supportive management structures, well-designed communication systems, and compatibility of design and construction. The barriers can include risk taking, inefficiency, codes and budget, transparency, lack of trust, too much conflict, and frustrations with defensive behavior, scarcity of resources and return of investment [23]. In the literature, realization of construction innovation is conducted in two parts. One is vertical. In vertical dissemination, products, services, and information are shared among stakeholders during the project. The other is horizontal dissemination. This emerges from stakeholders utilizing information, products, and services in a project [23]. In another study, types of innovation in the construction industry were distinguished as "information technologies", "computer based electronic devices", "end products", "construction means and methods" and "construction equipment" [7].

During the last few decades, investigation of a company's success in terms of qualitative factors has been a fertile subject of research in construction management literature. Several models were developed to measure the performance of a construction company or projects success. However literature findings indicated that there is limited research on models considering the innovational or technology transfer performance of companies and 
projects. In [8] the authors investigated the relationship between project-based, service-enhanced companies and innovation in complex construction products. They offered a model in which the knowledge obtained from the project is integrated to the intellectual resources of companies. Their model focused on business and project processes. In another study [26] the authors investigated strategic decisions' impact on innovation considering the company size. In another study on strategies and innovation [16], the authors considered five types of strategies to see their impact on innovation outcomes. These strategies were "employee, technology, marketing, knowledge, and relationship strategies". These strategies were investigated at companies that use both high and low levels of innovation to address important strategies used throughout the entire construction industry. One of the studies conducted by the authors in [35] was a conceptual framework of construction innovation. They took into account "innovation input", "drivers", "antecedents" and "innovation outcome". In [19] the author divided innovation processes into seven categories such as drivers, inputs, enablers, barriers, innovative activities, benefits, and impacts. In [20] the authors investigated systematic innovation in construction companies with factors such as "drivers of innovation", "business environment", "organizational capabilities" and "company competitiveness".

In this study, the effects of "Internal capabilities" of a construction company such as "Resources and capabilities", "Project management competencies" and "Strategic decisions" on indicators of a company's "Innovation and technology transfer success" were investigated. Indicators of "Innovation and technology transfer success" were associated with parameters such as "higher perceived value", "completion of the projects held by the company on time and within budget", "competitive advantage", "reputation", "productivity", "financial indicators", "learning and development" and "customer satisfaction". For this purpose a questionnaire survey was administered to internationally working construction contractor companies. Structural Equation Modeling Method was used to analyze data and construct the model showing the interrelationships between the factors and examine the effects.

\section{Proposed model variables}

A construction company's success can be basically defined in terms of its profitability and project success. However, long-term goals, strategies and competitiveness in the industrial environment force companies to measure their success with some strategic indicators such as innovation and technology transfer which also provide competitive advantage. A company's success has a complex structure that is, as it is hypothesized in this study, effected by the internal capabilities such as company's resources and capabilities, project management competencies as well as its strategic decisions. In this section after having an overview of internal capabilities, indicators of construction companies' innovation and technology transfer variables will also be identified.

\subsection{Resources and capabilities}

A company's resources and capabilities can be investigated by examining the company's brand, corporate identity, image in society, know-how, experience, learning capacity leadership, organizational culture, and technological secrets.

Know-how, Experience and Learning Capacity: Know-how is used as a competitive advantage tool by companies. Moreover, know-how allows companies to respond to changing market conditions. In [10] the authors' research showed that company reputation, product reputation and employee know-how are key performance indicators of company success. Also companies benefit from collaborative know-how and partners' experience. Another important criteria in utilizing and storing of knowledge is learning capacity. Learning capacity has a direct impact on benefiting from innovation and technology transfer results.

Leadership: In [6] the authors divide managerial leadership into three categories: project leadership, technical leadership, and team leadership. These properties of leadership help to achieve the project's innovational vision and strategy. Furthermore, it is beneficial to unite project participants in a common goal.

Brand, Corporate Identity: Brands create trust so that companies can positively influence customers' perceptions of products or services. Furthermore, an innovational brand recognition provides flexibility for solving business problems.

Technological Secrets: Knowledge discovered by a company, which consists of an industrial-commercial process and is withheld from competitors.

Organizational Culture: Technological advancements should be compatible with organizational culture, and also the culture should be reshaped by those advancements. Organizational culture consists of shared items upon which organization members develop common attributes. The strength of culture can be shown through the adaptability to the innovational advancements as well as the organizational history, group members' stability and the intensity of group experience [5].

\subsection{Project management competencies}

Project management competencies of a company were associated with their practices in energy, knowledge, health and safety, value, quality, cost, risk, procurement and time management.

Energy Management: Energy management is the strategy of meeting an energy demand when and where it is needed. Nowadays, governments promote and companies follow energy saving policies since they are advantageous to commerce, competition, and environmental hazard reduction.

Knowledge Management: Companies apply knowledge management in order to gain competitive advantage. Knowledge management prompts organizational performance, competition, problem solving, innovation, and cost effectiveness. Although knowledge management aims to mine, record, and disseminate explicit knowledge in an organization, it also tries to convert implicit knowledge to explicit knowledge. 
Value Management: Value management can be succinctly described as getting the best value for the money. This management area relies upon technological advances, industrial competition, and clients' needs and demands in order to make progress.

Health and Safety Management: Innovations and technology transfers can be beneficial in order to avoid health and safety problems in the projects [19]. It also has a positive impact on labor productivity and performance in order to constitute healty conditions in workplace.

Quality Management: In [13] the authors examined the effect of quality management on innovation with factors such as process flow management, product design process, statistical control/feedback, customer relationship, work attitude, workforce management and top management support. They found that process management has a direct impact on radical product innovation, incremental product innovation, radical process innovation, incremental process innovation, and administrative innovation in quality management.

Cost Management: Completing a project within the planned budget requires cost management, estimation, determination and controlling [22]. Innovations will affect cost of the project as well as the project complexity, procurement methods, tendering method and project size [14].

Risk Management: Risk management involves several processes such as planning of risk management, identification of risk factors, qualitative risk management analyses, quantitative risk management analyses, planning of risk response, and control of risks [22].

Procurement Management: Logistics of the material and equipment supplies in the projects causes delays if it is not managed well. In different circumstances, where logistics would cause delays, companies should choose their strategy between developing/producing or still supplying [22].

Time Management: Time management being one of the major components of project success includes innovational diverse tools and techniques that provide effective utilization of project resources within the planned duration of the project.

\subsection{Strategic decisions}

In the construction industry, companies' strategic decisions affect innovations and technology transfer activities either positively or negatively. In this study, nine different strategies were identified.

Subcontractor Selection Strategies: Selection of subcontractors is a dominant factor effecting project success since subcontractors take the responsibility of the contractors' tasks and accommodate to their implementation level of technology.

Differentiation Strategies: Differentiation strategy requires companies to be unique in their products or service offerings [21]. Differentiation strategy can be seen as innovative in the construction industry because it causes companies to compete against rivals on issues of price, innovation, quality and schedule.

Human Resources Strategies: Human resources are used as a transfer mechanism for transferring knowledge to companies. These strategies are used for effective utilization of human resources and know-how increase.

Cost Leadership Strategies: Cost leadership strategy is one of the most important competitive strategies revealed by the author in [21]. Cost leadership strategy aims to achieve the lowest price per unit using innovations and technology transfer activities.

Client Selection Strategies: The client is identified as the most significant driver of innovation in the projects since he invests in them [18]. Therefore clients' vision and needs should be compatible with the contractors' approach.

Market Selection Strategies: Market selection strategies require companies to specify their target markets so that they can specify target client groups, strategies, objectives, return, and both progress and workflow guidelines. These strategies can be employed when entering a new foreign market. Market selection is seen as one of the most important factors in company success.

Strategic Diversification (Horizontal, Vertical and Combined): Strategic diversification is divided into three parts. The first is horizontal strategy. When using horizontal strategy, companies produce new goods or services without leaving their original line of business. When using vertical strategies, companies establish a new business area where they begin performing formerlyoutsourced activities in their companies, or they work on end-products activities. When using a combined strategy, companies use both horizontal and vertical strategies [21].

Supplier Selection Strategies: In a competitive environment, supplier selection is strategic to companies. Nowadays, purchasing from third-party suppliers is becoming more common because internal and external parameters such as economical stability, financial power, contract specifications as well as time and budget constraints affect companies' purchasing decisions.

Investment Strategies: In the construction industry, each investment has an effect on the country's gross domestic product (GDP). Therefore, investment decisions of the companies should be well defined in order to have a positive impact on GDP. The research shows that the investments based on innovation and technology transfer have long time contributions on the GDP of any country [34].

\subsection{Indicators of construction companies' technology transfer and innovation success}

Indicators of a construction companies' technology transfer and innovation success that have been determined out of those mentioned in the literature are outlined below.

Higher Perceived Value: The effects of innovation and technology transfer activities are perceived in the outcomes of the project handled by the companies. This indicator can be defined as the quality that is gained as a result of innovation [13].

Completion of Project Within the Budget: Achieving the lowest cost possible as well as meeting the project's budget requirements are the major outcomes of a construction project as it is in timeliness. Innovations and technology transfer can be withheld in construction 
companies in order to minimize project activity costs as well as the operational costs at the corporate level [29].

Completion of Project on Time: In the execution of all projects there is a target date to finish and deliver the project. As being one of the major parameters of project success, all resources, capabilities and competencies work to avoid potential delays in a project. Innovations enable a project to finish more quickly.

Competitive Advantage Among Rivals: Innovations are essential to maintain a company's competitiveness. Some types of innovation give companies a competitive edge. The characteristics of this type of innovation are being difficult to reproduce, being amenable to market expectations, being pioneer at innovation and utilizing the innovation capacity [15].

Reputation/Company Image: A company's image or reputation is formed by consumer perception. Therefore, some companies select their strategies based upon customer desire. Having a perceived reputation for innovation leads consumers to innovative companies. Moreover, customers' participation in innovation affects products positively. Enhanced image is one of the results of innovation [19].

Productivity: In [10] the authors investigated the impact of innovation on productivity in small and medium-sized enterprises. They distinguished between product innovation and process innovation. After that, they separately investigated the effect of product and process innovation on productivity. They found that product innovation supports labor productivity. However, process innovation necessitates investment.

Financial Indicators: Financial perspective refers to the success of company in terms of profitability, turnover etc. [11]. In order to measure innovation at the company level, there are two different approaches such as research and development expenditures and proportion of personnel and profit to the launched products [33].

Learning and Development: Learning and development refer to the progress achieved by a company and its growth potential. Organizational learning capacity and the achievements of the organization in such areas as company image or various competencies are also taken into account in this perspective [11].

Satisfaction of Customer/Consumer: Companies try to meet customer demands and preferences in order to attain greater market share, so they apply innovation that can be used to create new demands within industries. However, in [27] the authors, who investigated the impact of innovation on customer satisfaction, found that marketing innovation has a greater impact on customer satisfaction than both product and process innovation.

\section{Research methodology}

Given the model described in the preceding section, four constructs were developed to measure the latent variables: "resources and capabilities", "project management competencies", "strategic decisions", and "indicators of construction companies technology transfer and innovation success". A questionnaire was developed to measure latent variables through the observed variables. The questionnaire was administered to 141 construction companies' (all members of the Contractors
Association) via e-mail and face-to-face interviews. The 141 companies received an e-mail describing the objective of the study, inquiring about their willingness to participate in the study and requesting a face-to-face interview with an executive of the company. 52 questionnaires were completed, the majority of which were administered by face-to-face interviews. The rate of response was $37 \%$. Looking at company demographic statistics, the firms had similar characteristics, such as international experience, number of years in construction industry and turnovers.

\subsection{Data analysis}

After collecting questionnaires from construction companies, Structural Equation Modelling methodology was used as a statistical analysis method. SEM methodology was used to convert unobserved variables into measurable variables. The SEM is composed of two parts. First, the measurement model is analyzed. After analyzing the measurement model, analysis of the structural model begins. In this process, the fit between the models and the survey results are examined. SEM combines a measurement model (confirmatory factor analysis) and a structural model (regression or path analysis) statistically. In this study, Eqs 6.2, a SEM software package, was used to perform the analysis. Constructing the measurement model is the first phase of SEM. The measurement model includes latent factors and their related indicators (observed variables). Both exploratory and confirmatory factor analysis can be used in the SEM measurement model. However, confirmatory factor analysis is more commonly used in the literature to gain direct relationships between variables. However, if it is needed to use exploratory factor analysis, all observed variables should be connected to all latent factors. Indicators are specified according to their high factor loads. Straight arrows, two headed arrows, errors, latent factors, and observed variables (indicators) are used in the measurement models. The straight arrows are placed between latent factors and their indicators, and between errors and their observed variables respectively. Twoheaded variables are used between latent factors if there is a correlation between latent factors. If there is an unexplained variance between an indicator and a latent factor, this is shown with errors. In the SEM model, observed variables are symbolized with rectangular shapes while latent factors are symbolized with ovals. Although factor loadings between variables are important for accepting the model, they are not enough. Goodness of fit indexes must also be used. During the second phase, the structural model is investigated. At this phase, a cause and effect relationship is investigated. However, before testing, the merged measurement models are tested together. Afterwards, relationships between latent factors are investigated regardless of whether the results are expected. Goodness of fit statistics is used in order to make a final evaluation of the structural model. These statistics provide an information on the acceptability of the model in terms of whether the data collected from surveys support the model or not. When confirmatory factor analysis is implemented in the SEM, construct validity is provided. Validating constructs requires four 
stages. First, the model's content validity is required, and the constructed model is investigated regardless of whether a deep literature review has been conducted.

In this study, content validity is fulfilled. Accordingly, four latent variables and thirty-two variables were revealed. Before these variables were established, a pilot study had been performed. Secondly, the model's scale reliability testing was investigated. In this process, the model's Cronbach's alpha value was measured. This value must be, at minimum, 0,7 [17]. Cronbach's alpha value was 0,752 for resources and capabilities, 0,909 for strategic decisions, 0,886 for project management competencies, and 0,891 for indicators of success in terms of technology transfer and innovation. Therefore, minimum requirements were fulfilled. Thirdly, convergent validity testing was implemented to the constructed measurement models and structural model. In this phase, factor loadings and their meaningfulness were tested at $\alpha=0,05$. Outcomes of factor loadings are presented in Tab. 1.

Table 1 Latent and constituent variables with factor loadings in measurement models

\begin{tabular}{|c|c|c|}
\hline & Variables & $\begin{array}{l}\text { Factor } \\
\text { Loadings }\end{array}$ \\
\hline F1 & \multicolumn{2}{|l|}{ Resources and Capabilities } \\
\hline V1 & $\begin{array}{l}\text { Know-how, experience and learning } \\
\text { capacity }\end{array}$ & 0,789 \\
\hline $\mathrm{V} 2$ & Leadership & 0,851 \\
\hline V3 & $\begin{array}{l}\text { Brand, Corporate identity, Image in } \\
\text { society }\end{array}$ & 0,634 \\
\hline V4 & Technological secrets & 0,381 \\
\hline V5 & Organizational culture & 0,488 \\
\hline $\mathrm{F} 2$ & \multicolumn{2}{|l|}{ Project Management Competencies } \\
\hline V6 & Energy management & 0,401 \\
\hline V7 & Knowledge management & 0,739 \\
\hline V8 & Value management & 0,713 \\
\hline V9 & Health and safety management & 0,804 \\
\hline V10 & Quality management & 0,795 \\
\hline V11 & Cost management & 0,562 \\
\hline V12 & Risk management & 0,758 \\
\hline V13 & Procurement management & 0,908 \\
\hline V14 & Time management & 0,589 \\
\hline F3 & \multicolumn{2}{|l|}{ Strategic Decisions } \\
\hline V15 & Subcontractor selection strategies & 0,821 \\
\hline V16 & Differentiation strategies & 0,693 \\
\hline V17 & Human resources strategies & 0,625 \\
\hline V18 & Cost leadership strategies & 0,795 \\
\hline V19 & Client selection strategies & 0,529 \\
\hline V20 & Market selection strategies & 0,765 \\
\hline V21 & $\begin{array}{l}\text { Strategical diversification (horizontal, } \\
\text { vertical and combined) }\end{array}$ & 0,649 \\
\hline $\mathrm{V} 22$ & Supplier selection strategies & 0,846 \\
\hline V23 & Investment strategies & 0,821 \\
\hline F4 & \multicolumn{2}{|c|}{$\begin{array}{l}\text { Indicators of Construction Companies Technology } \\
\text { Transfer and Innovation Success }\end{array}$} \\
\hline V24 & Higher perceived value & 0,605 \\
\hline $\mathrm{V} 25$ & Completion of project on budget & 0,770 \\
\hline V26 & Completion of project on time & 0,769 \\
\hline V27 & Competitive advantage among rivals & 0,784 \\
\hline V28 & Reputation/Company image & 0,779 \\
\hline V29 & Productivity & 0,718 \\
\hline V30 & Financial indicators & 0,567 \\
\hline V31 & Learning and development & 0,672 \\
\hline V32 & Satisfaction of customer/consumer & 0,595 \\
\hline
\end{tabular}

Finally, discriminant validity testing was conducted on variables. When this test was performed on factors, all variables that have the same corresponding variables were assessed individually. In discriminant validity testing, correlations between variables were taken into consideration. The value of correlations must be below 0,90 [9]. If the value is higher than 0,90 , the variables have the same construct, and one variable must be considered in the model. All of this study's variables had values below 0,90 .

When the model was constructed during the SEM process, resources and capabilities, project management competencies, strategic decisions, and indicators of construction companies technology transfer and innovation success were evaluated in the same model. The model was assessed and all factor loadings were found to be significant at $\alpha=0,05$. In the final model, the Cronbach's alpha value was determined to be 0,951 . Observed variables' factor loadings and the path coefficient of latent variables are presented in Fig. 1. The analysis shows that all observed variables and latent variables stayed within the required ranges. However, these limitations are not suitable for assessing the whole model. Therefore, model fit indexes are used. In this study, model fit was assessed using the non-normed fit index (NNFI), comparative fit index (CFI), root mean square error of approximation (RMSEA) with a $90 \%$ confidence interval, and the model chi-square since they are not affected by sample size.

Moreover, robust methodology was used according to non-normal distribution. The model fit indexes are presented in Tab. 2. All results were found to be within the allowable ranges.

Table 2 Goodness of Fit-indexes

\begin{tabular}{|l|c|c|}
\hline \multicolumn{1}{|c|}{ Fit indexes } & Allowable ranges & Overall \\
\hline $\begin{array}{l}\text { Non-normed fit index } \\
(\text { NNFI })\end{array}$ & 0 (no fit) $\div 1$ (perfect fit) & 0,758 \\
\hline $\begin{array}{l}\text { Comparative fit index } \\
(\mathrm{CFI})\end{array}$ & 0 (no fit) $\div 1$ (perfect fit) & 0,775 \\
\hline RMSEA & $<0,1$ & 0,097 \\
\hline$\chi^{2} /$ degree of freedom & $<3$ & 1,4765 \\
\hline
\end{tabular}

\subsection{Discussion of findings}

In the literature, in [1] the authors state that lack of resources and capabilities influences construction companies. Therefore, "know-how, experience and learning capacity", "leadership", "brand, corporate identity, image in society", "technological secrets", and "organizational culture" are taken into consideration in this study.

According to the results, direct impact of "resources and capabilities" on innovation and technology transfer indicators were not found. Instead, the impact was seen via "project management competencies". This issue was also explained by the authors [4]. The authors stated that project management is responsible for a company's resources. If the impact of resources and capabilities is compared to "strategic decisions", results show that it has higher impact on "project management competencies" than on "strategic decisions" according to the path analysis score $(0,609 \div 0,404)$. 


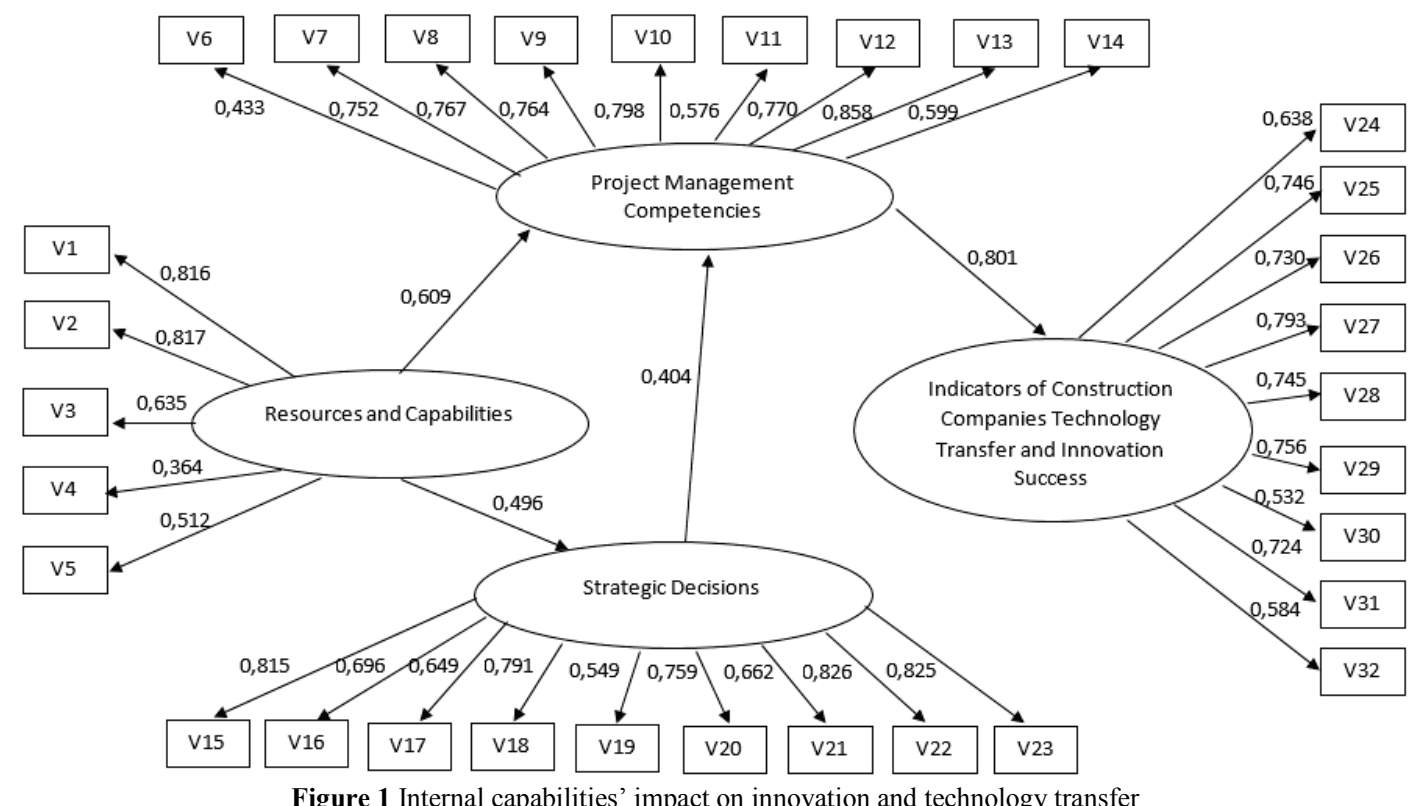

Analysis of the model shows that "resources and capabilities" impact both "project management competencies" and "strategic decisions". The impacts were found to be 0,609 for "impact of resources and capabilities on project management competencies" and 0,496 for "impact of resources and capabilities on strategic decisions". Analysis of "resources and capabilities" factor loadings show the variables to be 0,816 for "know-how, experience and learning capacity", 0,817 for "leadership", 0,635 for "brand, corporate identity, image in society", 0,364 for "technological secrets", and 0,512 for "organizational culture". The highest score in the model analysis was "leadership". This finding was supported by the authors in [24]. They stated that transformational leadership has an impact on organizational culture. They also say that organizational culture creates a supportive climate for organizational innovation. Furthermore, a study by the authors in [3] mentions this correlation.

\subsubsection{Effect of project management competencies}

The model found that "project management competencies" have a direct influence on performance. The importance of project management competencies was emphasized in the literature. According to a study by the authors in [12], strict project management methods impede innovational activities in construction industry. Another study that supports the indirect effect of project management on innovation was conducted by the authors in [8]. They stated that contractor and operator workloads put pressure on delivery time, budget, and quality.

According to the model analysis, the variables' factor loadings were found to be 0,433 for "energy management", 0,752 for "knowledge management", 0,767 for "value management", 0,764 for "health and safety management", 0,798 for "quality management", 0,576 for "cost management", 0,770 for "risk management", 0,858 for "procurement management", and 0,599 for "time management".

Based on the allowable results of the analysis, it can be asserted that "procurement management" in a company can be efficient in the execution of all innovation and technology transfer processes. Secondly, "quality management" is revealed as being a driving force on technology transfer and innovation in project management activities. These two variables affirm the nature of innovation and technology transfer in the construction industry.

Technology transfer activities are directly related to procurement management activities. Therefore, high factor loading of "procurement management" may originate for this reason. In the literature, in [8] the authors stated that challenges faced throughout the project can require companies to procure technology from outside of the company's resources. Another high loading factor of the model was "quality management". Literature findings show quality management activities, such as total quality management, have a positive impact on innovations [32]. Another study about this impact was conducted by the author in [3]. The author stated that strategic quality management has a positive impact on innovation management.

\subsubsection{Effect of strategic decisions}

"Strategic decision" had no direct effect on innovation and technology transfer in the construction industry, but had an indirect effect via "project management competencies". The importance of strategic decisions on innovation and technology transfer activities in the construction industry was investigated by the authors in [7]. According to the study, authors found that considering innovation as a part of strategies facilitates construction innovations. Another study that supports the importance of "strategic decisions" in construction innovation was performed by Barrett and Sexton [1]. They stated that business strategies can affect innovation in small, project-based construction firms. They considered strategy under the "upper management support". They concluded that strategic decisions about innovation play a facilitator role in the construction industry. Furthermore, "project management competencies" and "strategic decisions" are relatied. This 
relationship between business strategy and Project management can be two-way according to the authors in [28]. According to the analysis of SEM, "strategic decisions", which are described above, affect "project management competencies". Strategic decisions' variables support both "project management competencies" and "indicators of innovation and technology transfer" via "project management competencies" indirectly. Furthermore results of the SEM model analysis showed that "resources and capabilities" affect "strategic decisions".

In the light of the SEM results, these findings are proven. According to analysis of the model, "supplier selection strategies" were found to have the highest impact on "project management competencies". Another variable, "investment strategies", has a similar effect on "project management strategies" to "supplier selection strategies". Factor loadings of the variables were found to be 0,815 for "subcontractor selection strategies", 0,791 for "cost leadership strategies", 0,759 for "market selection strategies", 0,696 for "differentiation strategies", 0,662 for "strategical diversification", 0,649 for "human resources strategies", and 0,549 for "client selection strategies".

That "supplier selection strategies" received the highest score is supported by Schiele's [25] study. Schiele stated that innovation is the way for companies to survive. Therefore, they need to purchase new technologies, and innovative suppliers play an important role.

The second highest score was received as "investment strategies". This finding is supported by an explanation from the authors in [26]. They stated that "the focus of innovation is considered to be the business firm since that is where the benefits of the investment can be observed and measured". This shows that "investment strategies" are related to innovation and technology transfer activities.

Also among the highest scores is "cost leadership strategies", according to the analysis. In [31] the author stated that innovation can lower customer costs. This statement supports the positive impact cost leadership strategies have on innovation, according to the literature. Additionally, cost savings are seen in indicators of innovation and technology transfer activities indicators.

\section{Conclusion}

It was hypothesized in this study that construction companies' innovation and technology transfer success would be influenced by project management competencies, resources and capabilities, and strategic decisions of the company. Considering that all variables had an acceptable impact on their corresponding latent variables, SEM methodology was used in order to construct a model, analyze the hypothesized interrelationships within. According to the findings, all outcomes (Cronbach's alpha coefficients, NNFI, CFI, Chi-square, RMSEA, correlations, and factor loadings) stayed within allowable ranges. The internal reliability of the constructs and the overall model were quite high. CFA showed all factor loadings were significant at 0,05 . The goodness of fit indexes indicated a good fit. The reason why the fit indexes are not higher than 0,9 for NNFI and CFI indexes and less than 0,5 for RMSEA index can be explained with the sample size and the fact that in addition to internal capabilities some other variables would also be considered such as external factors which will also be investigated separately in a further study.

Given the strong path coefficients, the hypotheses set forward at the beginning of the study have been held. The model shows that if construction companies use certain internal capabilities, they can prompt their performance with innovation and technology transfer activities within their industry. The analysis also reveals that the model can also be used to measure construction companies' performance in terms of innovation and technology transfer which can be defined as an accepted strategic competitive advantage among their rivals in the industry. Following this study, the relationship between external factors and innovation and technology transfer should be investigated. Furthermore, reflection of innovation and technology transfer factors in the construction industry should be investigated by SEM methodology.

In the context of this study, the questionnaire was administered only to contractor companies. However, the construction industry has many subsectors. In order to develop a comprehensive innovation and technology transfer model, these questionnaires should also be administered to construction industry stakeholders. Another recommendation for further study is the development of a scorecard that can be used to rate companies' innovational and technological transfer activities providing benchmarking among companies.

\section{References}

[1] Barrett, P.; Sexton, M. Innovation in Small, Project-Based Construction Firms. // British Journal of Management. 17, 4(2006), pp. 331-346. DOI: 10.1111/j.1467-8551.2005.00461.x

[2] Blindenbach-Driessen, F.; Van Den Ende, J. Innovation in project-based firms: The context dependency of success factors. // Research Policy. 35, 4(2006), pp. 545-561. DOl: 10.1016/j.respol.2006.02.005

[3] Bossink, B. A. Innovative quality management practices in the Dutch construction industry. // International Journal of Quality Reliability Management. 19, 2(2002), pp. 170-186. DOI: 10.1108/02656710210413507

[4] Brady, T.; Rush, H.; Hobday, M.; Davies, A.; Probert, D.; Banerjee, S. Tools for technology management: an academic perspective. // Technovation. 17, 8(1997), pp. 417-426. DOI: 10.1016/S0166-4972(97)00017-5

[5] Cabrera, Á.; Cabrera, E. F.; Barajas, S. The key role of organizational culture in a multi-system view of technology-driven change. // International Journal of Information Management. 21, 3(2001), pp. 245-261. DOI: 10.1016/S0268-4012(01)00013-5

[6] Edum-Fotwe, F. T.; McCaffer, R. Developing project management competency: perspectives from the construction industry. // International Journal of Project Management. 18, 2(2000), pp. 111-124. DOI: 10.1016/S02637863(98)90075-8

[7] Gambatese, J. A.; Hallowell, M. Enabling and measuring innovation in the construction industry. // Construction Management and Economics. 29, 6(2011), pp. 553-567. DOI: $10.1080 / 01446193.2011 .570357$

[8] Gann, D. M.; Salter, A. J. Innovation in project-based, service-enhanced firms: the construction of complex products and systems. // Research policy. 29, 7(2000), pp. 955-972. DOI: 10.1016/S0048-7333(00)00114-1 
[9] Hair, Jr., J. F.; Anderson, R. E.; Tatham, R. L. and Black, W. S. Multivariate Data Analysis. Prentice-Hall, Englewood Cliffs, N. J., 1998.

[10] Hall, B. H.; Lotti, F.; Mairesse, J. Innovation and productivity in SMEs: empirical evidence for Italy. // Small Business Economics. 33, 1(2009), pp. 13-33. DOl: 10.1007/s11187-009-9184-8

[11] Kaplan, R. S.; Norton, D. P. The balanced scorecard: translating strategy into action. Harvard Business Press, Boston, Massachusetts, USA, 1996.

[12] Keegan, A.; Turner, J. R. The management of innovation in project-based firms. // Long range planning. 35, 4(2002), pp. 367-388. DOI: 10.1016/S0024-6301(02)00069-9

[13] Kim, D. Y.; Kumar, V.; Kumar, U. Relationship between quality management practices and innovation. // Journal of Operations Management. 30, 4(2012), pp. 295-315. DOI: 10.1016/j.jom.2012.02.003

[14] Kujala, J.; Brady, T.; Putila, J. Challenges of cost management in complex projects. // International Journal of Business and Management. 9, 11(2014), pp. 48. DOI: 10.5539/ijbm.v9n11p48

[15] Lengnick-Hall, C. A. Innovation and competitive advantage: What we know and what we need to learn. // Journal of Management. 18, 2(1992), pp. 399-429. DOI: $10.1177 / 014920639201800209$

[16] Manley, K.; McFallan, S.; Kajewski, S. Relationship between construction firm strategies and innovation outcomes. // Journal of construction engineering and management. 135, 8(2009), pp. 764-771. DOI: 10.1061/(ASCE)CO.1943-7862.0000030

[17] Nunally, J. Psychometric theory. McGraw-Hill, New York, 1978.

[18] Odeh, A. M.; Battaineh, H. T. Causes of construction delay: traditional contracts. // International journal of project management. 20, 1(2002), pp. 67-73. DOI: 10.1016/S0263-7863(00)00037-5

[19] Ozorhon, B. Analysis of construction innovation process at project level. // Journal of Management in Engineering. 29, 4(2012), pp. 455-463. DOI: 10.1061/(ASCE)ME.19435479.0000157

[20] Pellicer, E.; Yepes, V.; Correa, C. L.; Alarcón, L. F. Model for systematic innovation in construction companies. // Journal of Construction Engineering and Management. 140, 4(2014), B4014001. DOI: 10.1061/(ASCE)CO.19437862.0000700

[21] Porter, M. E. Competitive advantage: Creating and sustaining superior performance. The Free Press, New York, 1998.

[22] Project Management Institute. A guide to the Project Management Body of Knowledge. Global Standard, Pennsylvania, USA, 2008.

[23] Rigby, E. T.; McCoy, A. P.; Garvin, M. J. Toward Aligning Academic and Industry Understanding of Innovation in the Construction Industry. // International Journal of Construction Education and Research. 8, 4(2012), pp. 243259. DOI: 10.1080/15578771.2012.663861

[24] Sarros, J. C.; Cooper, B. K.; Santora, J. C. Building a climate for innovation through transformational leadership and organizational culture. // Journal of Leadership Organizational Studies. 15, 2(2008), pp. 145-158. DOI: $10.1177 / 1548051808324100$

[25] Schiele, H. Early supplier integration: the dual role of purchasing in new product development. // R\&D Management. 40, 2(2010), pp. 138-153. DOI: 10.1111/j.14679310.2010.00602.x

[26] Seaden, G.; Guolla, M.; Doutriaux, J.; Nash, J. Strategic decisions and innovation in construction firms. // Construction Management and Economics. 21, 6(2003), pp. 603-612. DOI: 10.1080/0144619032000134138
[27] Simon, A.; Honore Petnji Yaya, L. Improving innovation and customer satisfaction through systems integration. // Industrial Management Data Systems. 112, 7(2012), pp. 1026-1043. DOI: 10.1061/(ASCE)0733-9364(2003)129:5(485)

[28] Srivannaboon, S.; Milosevic, D. Z. A two-way influence between business strategy and project management. // International Journal of Project Management. 24, 6(2006), pp. 493-505. DOI: 10.1016/j.jproman.2006.03.006

[29] Tatum, C. B. Potential mechanisms for construction innovation. // Journal of Construction Engineering and Management. 112, 2(1986), pp. 178-191. DOI: 10.1061/(ASCE)0733-9364(1986)112:2(178)

[30] Tatum, C. B. Organizing to increase innovation in construction firms. // Journal of Construction Engineering and Management. 115, 4(1989), pp. 602-617. DOI: 10.1061/(ASCE)0733-9364(1989)115:4(602)

[31] Teece, D. J. Capturing value from technological innovation: Integration, strategic partnering, and licensing decisions. // Interfaces. 18, 3(1988), pp. 46-61. DOI: 10.1287/inte.18.3.46

[32] Thai Hoang, D.; Igel, B.; Laosirihongthong, T. The impact of total quality management on innovation: Findings from a developing country. // International journal of quality reliability management. $23,9(2006)$, pp. 1092-1117. DOI: 10.1108/02656710610704230

[33] Tidd, J. Innovation management in context: environment, organization and performance. // International Journal of Management Reviews. 3, 3(2001), pp. 169-183.

[34] Zavadskas, E. K.; Ustinovichius, L.; Stasiulionis, A. Multicriteria valuation of commercial construction projects for investment purposes. // Journal of Civil Engineering and Management. 10, 2(2004), pp. 151-166. DOI: 10.1080/13923730.2004.9636299

[35] Xue, X.; Zhang, R.; Yang, R.; Dai, J. Innovation in Construction: A Critical Review and Future Research. // International Journal of Innovation Science. 6, 2(2014), pp. 111-126. DOI: 10.1260/1757-2223.6.2.111

\section{Authors' addresses}

Gökhan Demirdöğen, Research Assistant

Yildiz Technical University,

Department of Civil Engineering,

Construction Management Division,

Istanbul 34220, Turkey

E-mail: gokhand@yildiz.edu.tr

\section{Zeynep Işik, PhD, Assistant Professor}

Yildiz Technical University,

Department of Civil Engineering,

Construction Management Division,

Istanbul 34220, Turkey

E-mail: zeynep@yildiz.edu.tr 